\title{
E-learning as a complement to presential teaching of blindness prevention: a randomized clinical trial
}

\author{
'E-learning' como um complemento do ensino \\ presencial de prevenção da cegueira: ensaio clínico
}

Rodrigo Pessoa Cavalcanti Lira', João Paulo Fernandes Felix¹, Fernando Rodrigo Pedreira Chaves ${ }^{1}$, Enzo Augusto Medeiros Fulco ${ }^{1}$, Keila Miriam Monteiro de Carvalho', Anita Zimmermann

\begin{abstract}
Objective: To investigate if E-learning material improves the basal student knowledge level before attending the presential class of blindness prevention $(B P)$ and if helps to fix this information one-month after the class. Methods: Fourth-year medical students were randomly assigned to have a presential class of BP (Traditional group $=T G)$ or to have a presential class of BP plus an additional Elearning material $(E$-learning group $=E L G)$. This material was e-mailed one week before the presential class. The students were submitted to a multiple-choice test (with three options each) with seven questions immediately before the presential class, immediately after the class, and one-month later. The three tests had the same questions; however, the answers options were distributed in different sequences. The primary outcome was immediate pretest score. The secondary outcomes were immediate posttest score and one-month posttest score. Results: Among the 120 fourth-year medical students, a random sample of 34 students was assigned to the TG and 34 students was assigned to the ELG. The two groups showed similar immediate posttest score (TG=6.8 and ELG=6.9; $P<.754)$, but the differences at the immediate pretest score ( $T G=3.6$ and $E L G=4.7 ; P<.001$ ), and at the one-month posttest score, were significant (TG=6.1 and $E L G=6.8 ; P<.001)$. Conclusions: The pretest and the one-month posttest results suggested that the E-learning material acts as an effective complementary tool of the presential class of blindness prevention.
\end{abstract}

Keywords: Blindness/prevention \& control; Learning; Internet; Education, distance

www.clinicaltrials.gov NCT01249586

\section{RESUMO}

Objetivo: Avaliar se um material disponibilizado através de E-learning antes de aulas presenciais de prevenção da cegueira (PC) melhora o nível de conhecimento basal dos estudantes, e ajuda a manter esse conteúdo um mês após a aula. Métodos: Estudantes do quarto ano do curso médico foram aleatoriamente sorteados para ter aulas presenciais de PC (grupo tradicional = GT) ou ter aulas presenciais precedidas de material adicional por E-learning (grupo E-learning $=$ GEL). Este material foi enviado por correio eletrônico uma semana antes da aula presencial. Os estudantes foram submetidos a testes de múltipla escolha com sete questões (com três alternativas cada) imediatamente antes da aula presencial, imediatamente após a aula, e um mês após a aula. Os três testes tiveram as mesmas questões: entretanto, as respostas foram distribuídas em sequências diferentes. O desfecho primário foi a nota do pré-teste. Os desfechos secundários foram as notas dos pós-teste imediato e do pós-teste tardio. Resultados: Entre os 120 alunos do quarto ano de medicina, uma amostra aleatória de 34 alunos foi selecionada para o grupo GT e 34 alunos para o grupo GEL. Os dois grupos obtiveram nota similar no pós-teste imediato ( $\mathrm{GT}=6.8$ e $\mathrm{GEL}=6.9 ; \mathrm{P}<.754)$, porém diferenças estatisticamente significativas no pré-teste ( $\mathrm{GT}=3.6$ e GEL=4.7; $\mathrm{P}<.001)$, e no pós-teste tardio ( $\mathrm{GT}=6.1$ e $\mathrm{GEL}=6.8 ; \mathrm{P}<.001)$. Conclusão: Os resultados do pré-teste e do pós-teste tardio sugerem que o E-learning pode ser um complemento eficiente do ensino presencial de prevenção da cegueira.

Descritores: Cegueira/prevenção \& controle; Aprendizado; Internet; Educação à distância

www.clinicaltrials.gov NCT01249586

${ }^{1}$ Universidade Estadual de Campinas (UNICAMP) - Campinas (SP), Brazil.

Study carried out at Universidade Estadual de Campinas (UNICAMP) - Campinas (SP), Brazil.

The authors declare no conflicts of interest

Recebido para publicação em: 16/4/2012 - Aceito para publicação em: 3/9/2012 


\section{INTRODUCTION}

$\mathbf{T}$ There are 314 million people worldwide visually impaired; 45 million of them are blind. Most of them suffer from avoidable diseases and refractive errors. ${ }^{(1)}$ The three core approaches to eliminate avoidable visual impairment still are disease control, human resource development, and infrastructure and technology. The disease control and elimination require an adequately trained workforce ${ }^{(2,3)}$. One of the aims of educational programs of blindness prevention is to prepare an appropriately trained physician that will focus on the coverage, quality and sustainability of health services.

Training delivery on a computer has been around for more than thirty years ${ }^{(4)}$. E-learning refers to the use of internet technologies to deliver a broad array of solutions that enhance knowledge and performance. Online training is a viable mode of instruction. The learners' needs and the learning situation should always be foremost in the minds of training professionals. ${ }^{(5)}$

The aim of this study is to investigate if E-learning material improves the basal student knowledge level before attending the presential class of blindness prevention and if it helps to fix this information one-month after the class.

\section{Methods}

Among the 120 fourth-year medical students enrolled in the ophthalmology course at State University of Campinas, Brazil, sixty-eight students were randomly assigned to have a presential class of blindness prevention (Traditional group) or to have a presential class of blindness prevention plus an additional E-learning material (E-learning group). Sequential allocation was performed at the time of enrollment. The teacher was not informed of the study-group assignment of the students.

The students of both groups were informed about the study at the day of the presential class to prevent crossover bias.
The E-learning material included a PDF article about blindness prevention. ${ }^{(3)}$ This material was e-mailed one week before the presential class.

Participants were submitted to a multiple-choice test (with three options each) with seven questions about blindness prevention immediately before the Traditional class, immediately after the class, and one-month later. The three tests had the same questions; however the answers options were distributed in different sequences. The minimum score was $0(0 \%)$ and the maximal was $7(100 \%)$.

Age, gender and test scores were recorded on a standardized form. The primary outcome was immediate pretest score. The secondary outcomes were immediate posttest score and onemonth posttest score.

Ethics committee approval was obtained and all participants gave informed consent (CONEP- National Committee for Research Ethics - Brazil - 0218.0.146.000-10). Also the study was registered at Clinical Trials protocol NCT01249586.

A sample size of at least 60 students (30 per group) was planned to compare both groups for primary outcome (immediate pretest score). With an assumption of an immediate pretest score of $60 \%$ in the E-learning group, this sample size provided an $80 \%$ probability of detecting a difference as small as $10 \%$ in the standard group. Results of these analyses were considered as statistically significant when the $P$ values were $<.05$. The Epi Info computer software (United States Centers for Disease Control and Prevention, Atlanta, Georgia, United States of America) was used for the statistical analyses. For categorical variables, chi-square (Yates) tests were used, and for continuous variables, one-way analysis of variance (ANOVA) tables were used.

\section{RESULTS}

The sample consisted of 34 fourth-year medical students assigned to the E-learning group and 34 assigned to the Traditional group (Figure 1). Demographic data were comparable in the two groups (Table 1).

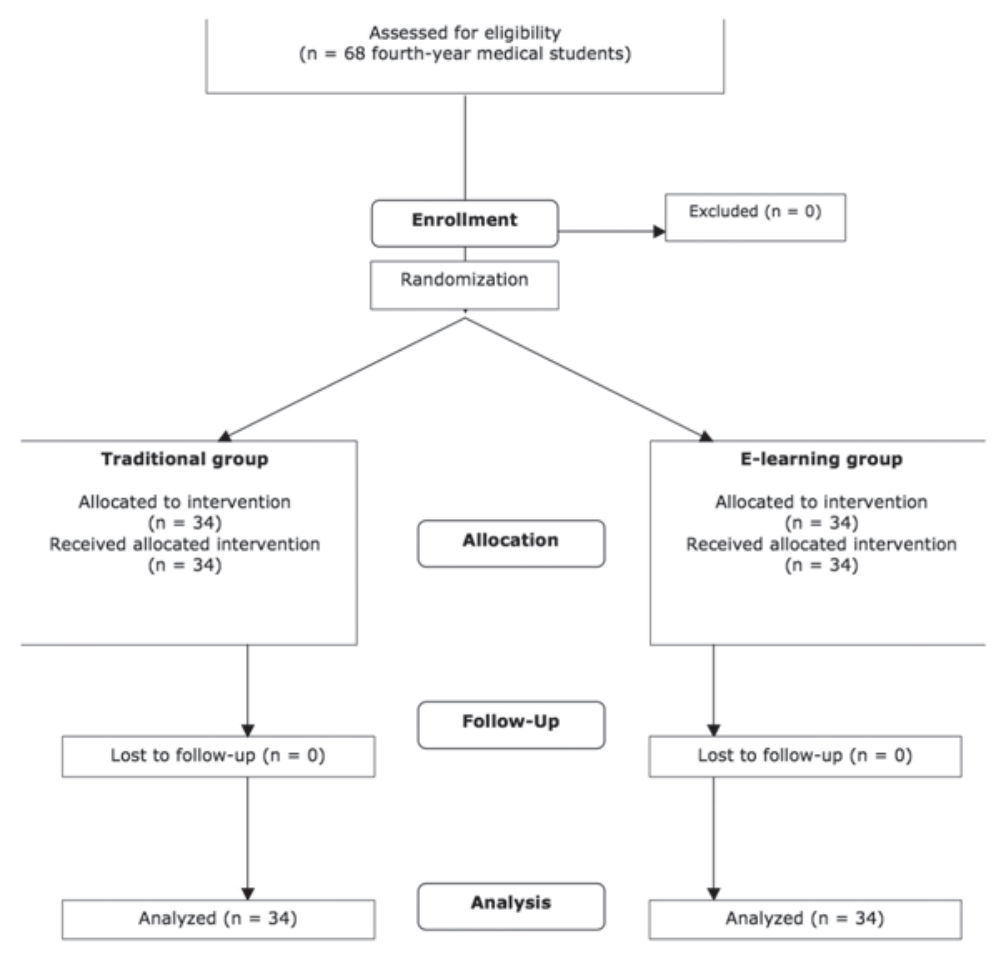

Figure 1: CONSORT flow diagram: e-learning as a complement to presential teaching of blindness prevention 
Table 1

Demographic data: e-learning as a complement
to presential teaching of blindness

Prevention

\begin{tabular}{lccc}
\hline Characteristics & $\begin{array}{c}\text { Traditional group } \\
(\mathbf{n = 3 4 )}\end{array}$ & $\begin{array}{c}\text { E-learning group } \\
(\mathbf{n = 3 4 )}\end{array}$ & p-value \\
\hline Age, mean (SD), y & $22,9(1,6)$ & $23,1(1,8)$ & $<.622$ \\
Male, No. $(\%)$ & $17(50)$ & $17(50)$ & $<.999$ \\
\hline
\end{tabular}

Table 2

Tests scores of the traditional group and of the e-learning group

\begin{tabular}{lcccccc}
\hline Time of evaluation & Traditional & group & E-learning & group & $\boldsymbol{P}$ value \\
\hline & Score (SD) & Range & Score (SD) & Range & \\
Immediate pretest & $3.59(1.28)$ & 1 to 6 & $4.71(0.58)$ & 4 to 6 & $<.001$ \\
Immediate posttest & $6.85(0.36)$ & 6 to 7 & $6.88(0.41)$ & 5 to 7 & $<.754$ \\
1-month posttest & $6.12(1.04)$ & 3 to 7 & $6.82(0.52)$ & 5 to 7 & $<.001$ \\
\hline
\end{tabular}

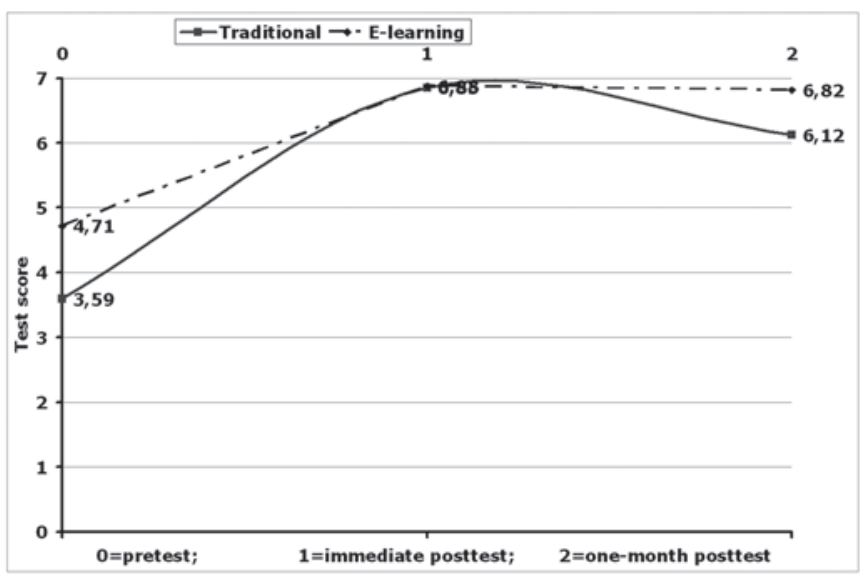

Figure 2: Tests scores of the traditional group and of the e-learning group

The immediate posttest scores were similar in the two groups $(P<.754)$, but the difference of the immediate pretest score $(P<.001)$ and of the one-month posttest score were statistically significant $(P<.001$ - Table 2 and Figure 2$)$.

In the Traditional group, the difference of the immediate pretest score (3.59) and the immediate posttest score (6.85), and the difference of the immediate posttest score (6.85) and the one-month posttest score (6.12) were both statistically significant $(P<.001)$.

In the E-learning group, the difference of the immediate pretest score (4.71) and the immediate posttest score (6.88) was statistically significant $(P<.001)$, but the difference of the immediate posttest score $(6.88)$ and the one-month posttest score (6.82) was not statistically significant $(P<.606)$.

\section{DisCUSSION}

The results demonstrated that the E-learning material acts as an effective tool on teaching of blindness prevention. If there was no significant difference in the pre- and post- test scores of the E-learning group, it would mean e-learning could replace Traditional teaching. But the additional gain of performance of the elearning group at the immediate posttest highlights that both methods (e-learning and presential teaching) complement each other.

The E-learning group pretest score was $31 \%$ higher than the Traditional group, and with less variability (SD 0.58 vs. SD 1.28 , respectively), demonstrating that E-learning tools help to improve the basal student knowledge level before attending the presential class.

The immediate posttest scores were not statistically different, and showed low variability, demonstrating that the prompt effect of presential class delivery on both groups was similar.

Despite the immediate posttest results, the one-month posttest score of the E-learning group was $11 \%$ higher than the Traditional group, and with less variability (SD 0.52 vs. SD 1.04, respectively), demonstrating that E-learning tools help to fix this information one-month after the class.

In diverse medical education contexts, E-learning appears to be at least as effective as traditional instructor-led methods such as lectures. Students do not see E-learning as replacing traditional instructor-led training but as a complement to it, forming part of a blended-learning strategy $\mathrm{y}^{(6,7)}$.

Innovations in E-learning technologies point toward a revolution in education, allowing learning to be individualized (adaptive learning), enhancing interactions of learners with others (collaborative learning), and transforming the role of the teacher. The integration of E-learning into medical education can catalyze the shift toward applying adult learning theory, where educators will no longer serve mainly as content distributors, but will become more involved as learning facilitators and compe- 
tency assessors ${ }^{(6,8)}$.

The E-learning may also be an important educational tool to reduce costs in updating information, especially in developing country, where teaching resources are limited. It allows the exchange of experiences between professionals, promotes simultaneous knowledge acquisition by a large number of participants, and reaches people in remote areas ${ }^{(9)}$.

There are some potential limitations of the E-learning method in this study. For example, the students must to have internet access, and both teachers and students need to acquire minimal familiarity with software and technology, but this is not usually a barrier in medicine courses. Students today are different from previous generations of students. Technology is an integral part of who they are and what they do outside of $\operatorname{school}^{(10,11)}$. Another limitation of this study is that students were not tested for retention of information sometime after completing the medicine course.

\section{CONCLUSION}

The results of this study suggested that E-learning can be used by medical educators to improve the efficiency and effectiveness of educational interventions. It is necessary to combine various pedagogical approaches with work toward the goal of eliminating avoidable blindness, which affects the quality of life of so many people, with such devastating consequences to human, social and economic development.

\section{RefEReNCES}

1. World Health Organization. WHO monitoring committee for the elimination of avoidable blindness: report of the second meeting. Geneva:WHO Press; 2010.

2. Temporini ER, Kara-José N. A perda da visão: estratégias de prevenção. Arq Bras Oftalmol. 2004;67(4):597-601.
3. World Health Organizatio. Global initiative for the elimination of avoidable blindness: action plan 2006-2011. Geneva:WHO Press; 2007.

4. Clark RC, Mayer RE. E-learning and the science of instruction: proven guidelines for consumers and designers of multimedia learning. 2nd ed. New York: Pfeiffer;2007.

5. Rosenberg MJ.E-learning: strategies for delivering knowledge in the digital age. New York: McGraw-Hill; 2000.

6. Ruiz JG, Mintzer MJ, Leipzig RM. The impact of E-learning in medical education. Acad Med. 2006;81(3):207-12.

7. Diessl S, Verburg FA, Hoernlein A, Schumann M, Luster M, Reiners C. Evaluation of an internet-based e-learning module to introduce nuclear medicine to medical students: a feasibility study. Nucl Med Commun. 2010;31(12):1063-7.

8. Ward JP, Gordon J, Field MJ, Lehmann HP. Communication and information technology in medical education. Lancet. 2001;357(9258):7926. Erratum in Lancet 2001;357(9266):1452.

9. Guerra CM, Ramos MP, Penna VZ, Goto JM, Santi LQ, de Andrade Stempliuk V, et al. How to educate health care professionals in developing countries? A Brazilian experience. Am J Infect Control. 2010;38(6):491-3.

10. Weston ME, Bain A. The end of techno-critique: the naked truth about 1:1 laptop initiatives and educational change. J Technol Learn Assess. 2010;9(6) [cited 2011 June 25] Available from: http://ejournals.bc.edu/ ojs/index.php/jtla/article/view/1611/1458

11. Johnson CE, Hurtubise LC, Castrop J, French G, Groner J, Ladinsky M, et al. Learning management systems: technology to measure the medical knowledge competency of the ACGME. Med Educ. 2004;38(6):599-608.

\section{Corresponding author}

Rodrigo Pessoa Cavalcanti Lira

Rua Irmã Maria David, 200 - ap 1302

Zip code: 52061-070 - Recife (PE), Brazil

Phone/fax 55 (81) 2102-0999

E-mail: rodrigopclira@hotmail.com 